\title{
KEBERHASILAN TEKNIK HYDROSEEDING UNTUK KONTROL EROSI PADA LAHAN MARGINAL SITE LATI PT BERAU COAL KABUPATEN BERAU PROVINSI KALIMANTAN TIMUR
}

\author{
Hifzil Kirmi ${ }^{1)}$, Muhammad Masyhuri ${ }^{2)}$ \\ Email; muhammad.masyhuri@beraucoal.co.id \\ ${ }^{1)}$ Environment Manager, ${ }^{2)}$ Revegetation Engineer PT Berau Coal
}

\begin{abstract}
ABSTRAK
Kegiatan penambangan batu bara PT Berau Coal site Lati menggunakan teknik open pit mining yang mana salah satu pengaruh negatif dari kegiatan operasional yakni potensi terjadinya pencemaran lingkungan meliputi pencemaran air karena terjadi erosi dan sedimentasi sungai dan juga terbentuknya areal revegetasi dengan tingkat kesuburan yang rendah. Untuk mengurangi dampak negatif salah satunya dengan penanaman mengguankan teknologi hydroseeding. Metode yang digunakan adalah penilaian keberhasilan covering covercrop hydroseeding dengan ground cover assassment, pendugaan laju erosi dengan USLE dan analisa kesuburan tanah kandungan $\mathrm{pH}$ dan $\mathrm{C} / \mathrm{N}$ rasio. Hasil penelitian menunjukan areal revegetasi yang belum ditumbuhi covercrop mempunyai laju erosi sangat tinggi dan kesuburan tanah yang rendah, sedangkan pada areal yang sudah ditanamai covercrop dengan teknologi hydroseeding mempunyai tingkat laju erosi rendah dan kesuburan tanah yang senderung meningkat serta keberhasilan penutupan covercrop yang tinggi pada lahan marginal.
\end{abstract}

Kata kunci : hydroseeding, lahan marginal, erosi, tanah

\begin{abstract}
PT Berau Coal site Lati coal mining activities use open pit mining technique, which is one of the negative effects of operational activities, namely the potential for environmental pollution including water pollution due to erosion and sedimentation of the river and also the formation of revegetation areas with low fertility. To reduce the negative impacts, one of them is by planting using hydroseeding technology. The method used is an assessment of the success of covering cover crop hydroseeding with ground cover assassment, estimating the rate of erosion with USLE and analyzing soil fertility with $\mathrm{pH}$ and $\mathrm{C} / \mathrm{N}$ ratio. The results showed revegetation areas that have not been covered with covercrop have very high erosion rates and low soil fertility, whereas in areas that have been planted with covercrop with hydroseeding technology have low erosion rates and soil fertility which is inclined to increase and the success of covercrop cover is high on land marginal.
\end{abstract}

Keywords: hydroseeding, marginal land, erosion, soil

\section{A. PENDAHULUAN}

\section{A.1. Latar Belakang}

Kegiatan penambangan batu bara dengan teknik open pit mining menimbulkan dampak terhadap perubahan bentang alam sehingga memberikan pengaruh positif ataupun negatif terhadap lingkungan. Salah satu pengaruh negatif yakni terjadinya pencemaran lingkungan meliputi pencemaran air dan sedimentasi sungai. 
Kegiatan reklamasi dan revegetasi merupakan bagian yang tidak terpisahkan dari proses penambangan untuk meminimalisir dampak terjadinya pencemaran air dan sedimentasi sungai, pada kegiatan ini yang menjadi tantangan adalah penanaman pada lahan marginal, pada lahan ini tamanan berpotensi mengalami stagnasi bahkan sampai pada tingkat kematian tanaman (yadi 2008). Pada kegiatan reklamasi jika kondisi lahan dibiarkan terbuka tanpa penanaman covercrop maka akan terus terjadi akselerasi pencucian unsur hara, erosi dan sedimentasi. Tahapan kegiatan reklamasi dan revegetasi PT Berau Coal meliputi kegiatan sebagai berikut:

a) Penanaman covercrop baik dengan teknik konvensional atau mekanis (hydroseeding)

b) Penanaman pohon jenis pionir

c) Penanaman pohon lokal / sisipan

Tahapan kegiatan reklamasi dan revegetasi ini merupakan bagian yang tidak terpisahkan dari proses pemulihan lahan paska tambang.

Sampai dengan bulan Agustus 2019 seluruh areal revegetasi PT Berau Coal seluas 4.305,30 Ha terdistribusi disemua areal operasi site Binungan, Sambarata dan Lati. Untuk pelaksanaan areal penelitian dilakukan di site lati areal IPD West, Secara geografis lokasi studi terletak pada koordinat $01^{\circ} 52^{\prime 2} 26,67^{\prime \prime L U}-02^{\circ} 2,5^{\prime} 09,78^{\prime \prime} \mathrm{LU}$ dan 117"07'44,52"BT-117'38'26,46"BT.

\section{A.2. Tujuan}

Penanaman covercrop dengan teknik hydroseeding digunakan pada lahan marginal bertujuan sebagai berikut :

1) Membantu mempercepat pemulihan kondisi kesuburan tanah dengan penutupan covercrop yang maksimal

2) Mengurangi terjadinya akselerasi erosi saat terjadi aliran permukaan (run off)

3) Mengurangi percepatan pencucian unsur hara yang dapat mengurangi kesuburan tanah.

\section{B. METODE}

\section{B.1. Penanaman Covercrop Dengan Teknik Hydroseeding \& Penilaian keberhasilan dengan menggunakan analisa visual dan ground covering assassment}

Teknik penanaman menggunakan hydroseeding \& penilaian covering vegetasi pada lahan revegetasi menggunakan metode systematic sampling with random start, teknik ini dengan mengambil sample secara sistematik secara acak, dengan langkah membuat garis transek arah vertikal dan horizontal dengan plot sampel ukuran 2 meter x 2 meter pada setiap jarak 15 meter mengikuti arah garis transek horizontal dan vertikal. Setiap plot dihitung persentase covering pertumbuhan setiap jenis covercrop yang tumbuh, hasil rata-rata pertumbuhan covercrop setiap jenis dijumlahkan sehingga menjadi total covering covercrop yang hasilnya digunakan sebagai parameter keberhasilan pertumbuhan covercrop hydroseeding (Total Persentase Ground Cover) sesuai PERMENHUT P.60/Menhut-II/2009 sebagai berikut:

Tabel 1. Kriterial persentase keberhasilan penutupan tanaman covercrop

\begin{tabular}{cc}
\hline $\begin{array}{c}\text { Persentase Penutupan } \\
\text { Covercrop }\end{array}$ & Kelas Keberhasilan \\
$\geq 90 \%$ & Sangat Berhasil \\
$80 \%-89 \%$ & Berhasil \\
$70 \%-79 \%$ & Cukup Berhasil \\
$60 \%-69 \%$ & Kurang Berhasil \\
$\leq 60 \%$ & Tidak Berhasil \\
\hline
\end{tabular}




\section{B.2. Penilaian laju erosi dengan metode USLE}

Penetapan erosi dilakukan juga dengan menggunakan metode Universal Soil Loss Equation (USLE) sebagai pembanding. Metode ini merupakan salah satu metoda prediksi erosi yang sudah dipergunakan secara luas. Model ini bersifat universal dan sangat mudah untuk digunakan di indonesia. Rumus dari model ini adalah:

$$
\text { A = R.K.L.S.C.P }
$$

Dimana :

$\mathrm{A} \quad$ = besarnya erosi (ton ha ${ }^{-1}$ tahun $\left.^{-1}\right), \mathrm{R}=$ faktor erosivitas hujan, $\mathrm{K}$ = faktor erobilitas tanah, $\mathrm{LS}=$ faktor topografi $(\mathrm{L}=$ panjang lereng, dan $\mathrm{S}=$ kemiringan Lereng), $\mathrm{C}=$ faktor tanaman tanah, $\mathrm{P}=$ faktor pengelolaan / teknik konservasi tanah yang dipakai.

Penetapan potensi erosi dengan menggunakan metode USLE dilakukan untuk setiap PUP yang telah ditetapkan sebelumnya. Untuk setiap PUP ditetapkan nilai-nilai parameter yang diperlukan. Untuk kepentingan tersebut, maka data yang diperlukan adalah data hujan (erosivitas hujan), data tanah (erodibilitas tanah), data lereng (kemiringan dan panjang lereng), data penutupan vegetasi, dan data pengelolaan.

Selama survei, selain melakukan pengamatan langsung, juga dilakukan pengambilan contoh tanah. Pengambilan contoh dilakukan untuk setiap umur revegetasi yang ditetapkan sebagai PUP. Jenis contoh tanah yang diambil adalah contoh tanah terganggu untuk analisis tekstur dan bahan organik serta contoh tanah utuh untuk analisis permeabilitas. Data tekstur, bahan organik, dan permeabilitas diperlukan untuk penetapan nilai kepekaan erosi tanah.

\section{B.2.1 Penetapan Erosivitas Hujan}

Nilai erosivitas hujan ditetapkan dengan menggunakan data rata-rata curah hujan bulanan (dalam cm) berdasarkan rumus Lenvain (DHV, 1989 dalam Asdak, 2007) sebagai berikut :

$$
\mathrm{Rm}=2,21 \times(\mathrm{CHm})^{1.36}
$$

Dimana $\mathrm{Rm}$ adalah erosivitas hujan bulanan (ton $\mathrm{m} / \mathrm{ha}$ tahun) dan $\mathrm{CHm}$ adalah rata-rata curah hujan bulanan dalam $\mathrm{cm}$. Erosivitas hujan tahunan adalah hasil penjumlahan dari erosivitas hujan bulanan dari Januari sampai Desember.

\section{B.2.2. Penetapan Faktor Lereng}

Nilai faktor lereng (LS) dihitung dengan rumus yang dikemukakan oleh Wischmeier dan Smith (1978) sebagai berikut:

$$
\mathrm{LS}=(\mathrm{x} / 22)^{\mathrm{m}}\left(0.43+0.30 \mathrm{~s}+0.043 \mathrm{~s}^{2}\right) / 6.613
$$

Dimana :

$\mathrm{x}=$ panjang lereng, $\mathrm{s}=$ persen kemiringan lereng, $(\mathrm{m}=0.5$ Bila lereng $\geq 5 \%, 0.4$ Bila lereng 3.5 $-4.5 \%, 0.3$ bila lereng $1-3 \%, 0.2$ bila lereng < $1 \%$ )

Pada kajian ini panjang lereng sangat bervariasi sehingga tidak dilakukan pengukuran, untuk itu panjang lereng ditetapkan berdasarkan pendekatan atau asumsi yaitu $50 \mathrm{~m}$ untuk areal dengan kemiringan $>8 \%$ dan 75 meter untuk areal dengan kemiringan lereng $<8 \%$.

\section{B.2.3. Penetapan Erodibilitas}

Nilai erodibilitas tanah (K) dihitung dengan rumus seperti dikemukakan dalam Arsyad ( 2010) sebagai berikut:

$$
100 \mathrm{~K}=2.713 \mathrm{M}^{1.14}\left(10^{-4}\right)(12-\mathrm{a})+3.25(\mathrm{~b}-2)+2.5(\mathrm{c}-3)
$$


Dimana :

$\mathrm{M}=$ Parameter ukuran butir $=(\%$ debu $+\%$ pasir halus $) \mathrm{x}(100-\%$ liat $) \mathrm{a}=\%$ Bahan organik tanah, $\mathrm{b}=$ Nilai kelas struktur (Tabel 2), $\mathrm{c}=$ Nilai kelas permeabilitas profil tanah (Tabel 3)

Catatan: Untuk kepentingan perhitungan nilai $\mathrm{K}$, analisis tekstur tanah minimal 4 fraksi, yaitu Pasir halus - $\operatorname{kasar}(0.1-2 \mathrm{~mm})$, pasir sangat halus $(50-100 \mu)$, debu $(2-50 \mu)$, dan liat $(<2 \mu)$.

Tabel. 2 Nilai b untuk Kelas Struktur Tanah

\begin{tabular}{clc}
\hline No & \multicolumn{1}{c}{ Kelas Struktur } & Nilai b \\
\hline 1 & Granular sangat halus $(<1 \mathrm{~mm})$ & 1 \\
2 & Granular halus $(1-2 \mathrm{~mm})$ & 2 \\
3 & Granular sedang \& kasar $(>2 \mathrm{~mm})$ & 3 \\
4 & Gumpal, lempeng, massive & 4 \\
\hline
\end{tabular}

Tabel. 3 Nilai c untuk Kelas Permeabilitas Profil Tanah

\begin{tabular}{clcc}
\hline No & \multicolumn{1}{c}{ Kelas Permeabilitas } & $\begin{array}{c}\text { Laju Permeabilitas } \\
(\mathbf{c m} / \mathbf{j a m})\end{array}$ & Nilai c \\
\hline 1 & Sangat cepat & $>25,4$ & 1 \\
2 & Cepat & $12,7-25,4$ & 2 \\
3 & Sedang & $6,3-12,7$ & 3 \\
4 & Lambat - sedang & $2,0-6,3$ & 4 \\
5 & Lambat & $0,5-2,0$ & 5 \\
6 & Sangat lambat & $<0,5$ & 6 \\
\hline
\end{tabular}

\section{B.2.4 Penetapan Nilai Faktor Tanaman}

Faktor tanaman (faktor C) merupakan resultante (pengaruh gabungan) antara berbagai strata covercrop penutupan tanaman. Pada kajian ini, strata covercrop ditetapkan 3 kelas, yaitu $>2 \mathrm{~m}, 0.5$ $-2 \mathrm{~m}$, dan $<0.5 \mathrm{~m}$ (basal cover). Masing-masing strata ditetapkan nilai faktor tanamannya dengan menggunakan nomograf seperti disajikan pada Gambar 1. Nilai C gabungan kemudian diperoleh dengan mengalikan semua nilai faktor tanaman pada semua strata.

Untuk faktor pengelolaan/tindakan konservasi nilainya ditetapkan sama dengan 1. Hal ini karena faktor pengelolaan atau tindakan konservasi sudah terintegrasi pada faktor lereng (pengaturan lereng) dan faktor tanaman.



Gambar 1. Nomograf untuk menetapkan nilai $\mathrm{C}$ untuk setiap ketinggian dan persentase penutupan covercrop tertentu 


\section{B.2.5. Analisa Kesuburan Tanah}

Pengambilan sampel tanah secara random sampling sebanyak 9 titik pada areal yang belum dilakukan hydroseeding dengan areal hydroseeding pada umur 1 tahun 8 bulan dan dilakukan analisa laboratorium tanah di fakultas pertanian universitas mulawarman.

\section{HASIL DAN PEMBAHASAN}

\section{C.1. Teknik Hydroseeding Pada Lahan Marginal \& Penilaian Keberhasilan Covering Covercrop}

Pada areal IPD West site Lati merupakan areal marginal dengan $\mathrm{pH}$ rata-rata 3,7 kegiatan penanaman covercrop dengan menggunakan hydroseeding dengan campuran material mulsa, kompos, pupuk organik, humega/asam humus, perekat dan biji covercrop. Hasil pemantauan dengan menggunakan metode ground covering assassment metode systematic sampling with random start mempunyai keberhasilan yang sangat bagus dengan nilai covering areal sebesar $90 \%$, berikut tabel hasil penilaian areal IPD west site lati :

Tabel.4 hasil penilaian covering covercrop IPD West Site Lati

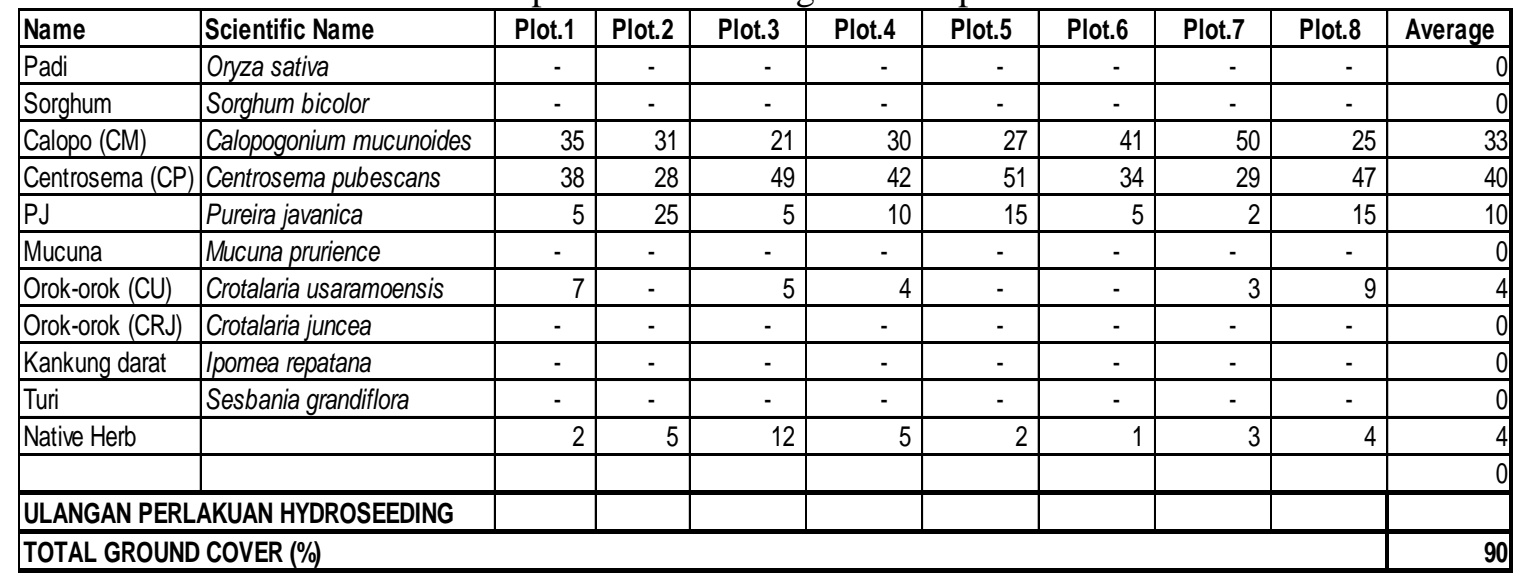

Gambar 2 menunjukkan foto areal IPD West sebelum dan sesudah dilakukan penanaman menggunakan teknik mekanis hydroseeding

\section{C.2. Tingkat Laju Erosi}

Pendugaan laju erosi dengan menggunakan metode USLE memerlukan pendugaan nilai-nilai faktor-faktornya, yaitu faktor erosivitas hujan (R), faktor erodibilitas tanah (K), faktor lereng (LS), faktor tanaman (C), dan faktor tindakan konservasi (P).

\section{C.2.1. Faktor Erosivitas Hujan}

Nilai erosivitas hujan dihitung dengan menggunakan metode Lenvain. Data hujan yang digunakan adalah data rata-rata curah hujan bulanan. Data rata-rata curah hujan bulanan dan nilai erosivitas hujan untuk Site Lati, Site Sambarata, dan Site Binungan disajikan pada Tabel 5. menunjukkan bahwa nilai erosivitas hujan di ketiga site tergolong tinggi, yaitu sekitar 2067.0 ton.m/hektar per tahun, mempunyai rata-rata curah hujan tahunan $2921.1 \mathrm{~mm}$ dan agak merata sepanjang tahun, tanpa bulan kering dengan rata-rata curah hujan bulanan terendah adalah $149.0 \mathrm{~mm}$ dan rata-rata curah hujan tertinggi adalah $303.5 \mathrm{~mm}$. 


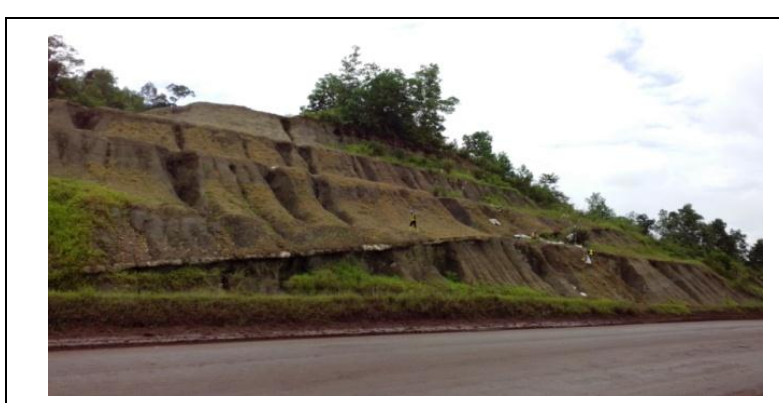

Foto.1 Areal hydroseeding sebelum di lakukan penyemprotan (1 Januari 2018)



Foto.3 Areal hydroseeding sebelum di lakukan penyemprotan (1 Januari 2018)

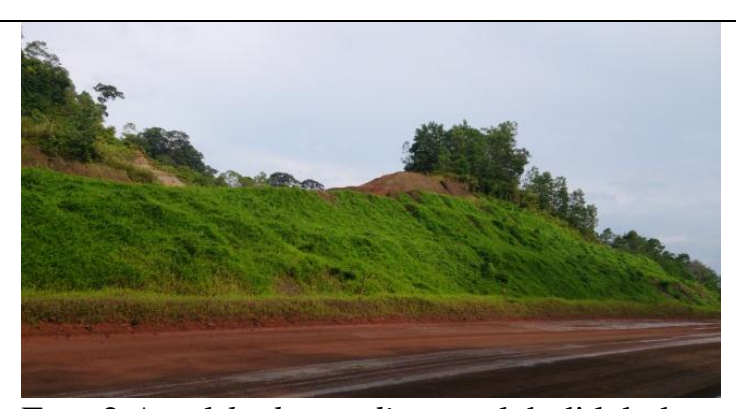

Foto.2 Areal hydroseeding setelah di lakukan penyemprotan (31 Agustus 2019)



Foto.4 Areal hydroseeding setelah di lakukan penyemprotan (31 Agustus 2019)

Gambar 2. Foto areal IPD West sebelum dan sesudah dilakukan penanaman menggunakan teknik mekanis hydroseeding

Tabel 5 Rata-rata curah hujan bulanan dan nilai erosivitas hujan tahunan di Site Lati

\begin{tabular}{|l|r|r|}
\hline \multicolumn{1}{|c|}{ Bulan } & Curah Hujan $\mathbf{( ~ m m )}$ & \multicolumn{1}{c|}{ Erosivitas Hujan } \\
\cline { 3 - 3 } & & (Ton m/Ha per tahun) \\
\hline Januari & 303,50 & $\mathbf{2 2 9 , 2 0}$ \\
\hline Februari & 246,60 & 173,80 \\
\hline Maret & 269,10 & 195,60 \\
\hline April & 255,70 & 182,60 \\
\hline Mei & 276,00 & 201,40 \\
\hline Juni & 191,80 & 123,70 \\
\hline Juli & 194,00 & 125,70 \\
\hline Agustus & 149,00 & 87,10 \\
\hline September & 183,30 & 115,40 \\
\hline Oktober & 235,00 & 162,80 \\
\hline November & 320,70 & $\mathbf{2 4 7 , 0 0}$ \\
\hline Desember & $\mathbf{2 9 6 , 3 0}$ & $\mathbf{2 2 2 , 8 0}$ \\
\hline Total & $\mathbf{2 9 2 1 , 0 0}$ & $\mathbf{2 0 6 7 , 1 0}$ \\
\hline
\end{tabular}

\section{C.2.2. Faktor Kepekaan Tanah Terhadap Erosi (Erodibilitas Tanah)}

Faktor kepekaan tanah terhadap erosi (K) pada metode USLE ditentukan oleh beberapa karakteristik tanah yaitu struktur, tekstur, bahan organik, dan permeabilitas. Makin tinggi nilai $\mathrm{K}$ tanah makin peka terhadap erosi. Kondisi struktur, tekstur, permeabilitas, dan bahan organik tanah dan nilai erodibilitas tanah (K) pada berbagai lokasi umur revegetasi dan hutan alam pada ketiga Site disajikan pada Tabel 6 
Tabel 6. Beberapa karakteristik tanah dominan dan nilai Erodibilitas Tanah di setiap kelompok umur revegetasi di Site Lati

\begin{tabular}{ccccccc}
\hline Umur & Struktur Tanah & Kelas Struktur & $\begin{array}{c}\text { Kelas } \\
\text { Permeabilitas }\end{array}$ & BO (\%) & \multicolumn{2}{c}{ Erodibilitas (K) } \\
\cline { 3 - 7 } & Gumpal - massif & $\begin{array}{c}\text { Lempung - liat - } \\
\text { berfragmen kasar }\end{array}$ & Lambat & 1,64 & 0,302 & SD \\
\hline 0 & Gumpal - massif & $\begin{array}{c}\text { Liat - berfragmen } \\
\text { kasar }\end{array}$ & Lambat & 4,05 & 0,251 & SD \\
\hline
\end{tabular}

Tabel tersebut menunjukkan bahwa nilai erodibilitas tanah site Lati tergolong sedang. Secara umum, erodibilitas tanah di areal tanpa revegetasi lebih tinggi dibandingkan dengan yang bervegetasi. Artinya tanah di lahan reklamasi bekas tambang tanpa covercrop lebih peka terhadap erosi. Hal ini terutama karena bahan organik yang rendah, struktur tanah yang kurang baik (belum terbentuk dengan baik), serta permeabilitas yang rendah (lambat).

\section{C.2.3. Faktor Lereng}

Secara umum, areal pemantauan revegetasi mempunyai bentuk wilayah datar-berombak sampai bergelombang dengan kemiringan yang bervariasi. Bentuk wilayah dengan kemiringan yang lebih curam dijumpai di lokasi hutan alami. Bentuk wilayah, kemiringan lereng dan nilai faktor LS untuk setiap lokasi pemantauan pada berbagai umur revegetasi dan hutan alam pada Site Lati, Site Sambarata, dan Site Binungan disajikan pada Tabel.7

Tabel 7. Kondisi lereng dan nilai faktor lereng di setiap umur revegetasi dan hutan alam

\begin{tabular}{cccc}
\multicolumn{4}{c}{ di Site Lati } \\
\hline $\begin{array}{c}\text { Umur } \\
\text { Revegetasi }\end{array}$ & Bentuk Wilayah & $\begin{array}{c}\text { Lereng Dominan } \\
(\boldsymbol{\%})\end{array}$ & Nilai Faktor LS \\
\hline 0 & Bergelombang & $8-15$ & 2,322 \\
1 & Berombak & $6-10$ & 1,756 \\
\hline
\end{tabular}

Catatan : lereng dominan adalah kemiringan lereng yang paling umum dijumpai disetiap lokasi pemantauan, pada spot-spot tertentu dijumpai juga lereng yang lebih curam, tapi tidak didelineasi karena sporadik

\section{C.2.4. Faktor Tanaman}

Faktor tanaman merupakan faktor yang paling dinamis yang menentukan erosi, karena kedua faktor ini mudah sekali berubah menurut waktu. Oleh karena itu, perbedaan erosi yang terjadi pada berbagai tingkatan umur revegetasi terkait langsung dengan kondisi faktor ini.

Faktor tanaman terutama ditentukan oleh karakteristik dan distribusi tutupan covercrop yang dapat meredam energi jatuhnya hujan dan gerusan aliran permukaan. Efektivitas redaman sangat tergantung pada tinggi covercrop dan kerapatan/persentase penutupan. Tutupan yang paling efektif meredam energi pukulan butir hujan dan gerusan aliran permukaan adalah tutupan dasar (basal cover) yang merupakan gabungan dari serasah dan tanaman merambat serta rerumputan.

Nilai faktor tanaman (C) pada setiap areal pemantauan menurut umur revegetasi disajikan pada

\section{Tabel 8}

Tabel 8. Persentase (\%) penutupan covercrop pada berbagai strata dan nilai faktor tanaman USLE (C) di setiap umur revegetasi dan hutan alam

\begin{tabular}{cccc}
\hline Umur Revegetasi & Persentase penutupan & \multicolumn{2}{c}{ Nilai CP } \\
\cline { 3 - 4 }$($ Tahun) & $(\%)$ & $\mathbf{2 0 1 8}$ & $\mathbf{2 0 1 9}$ \\
\hline 0 & 10 & - & - \\
1 & 90 & - & 0,290 \\
\hline
\end{tabular}


Sumber: Abdurachman et al., (1981) (Dimodifikasi)

Secara umum, kondisi penutupan covercrop makin baik dengan makin bertambahnya umur reklamasi, ditunjukkan oleh nilai persentase penutupan yang makin tinggi

\section{C.2.5. Pengelolaan/Tindakan Konservasi}

Faktor pengelolaan/tindakan konservasi tergantung pada jenis tindakan atau praktek konservasi yang dilakukan. Tindakan atau praktek konservasi yang telah dilakukan adalah pengaturan kemiringan lereng (pada saat landscaping) dan penggunaan tanaman penutup tanah. Kedua praktek ini pengaruhnya sudah diperhitungan pada saat menentukan nilai faktor lereng dan faktor tanaman. Oleh karena itu, nilai faktor tindakan konservasi pada kajian ini adalah dianggap sama dengan 1. Sumber: Abdurachman et al., (1981)

\section{C.2.6. Tingkat / Laju Erosi}

Berdasarkan nilai-nilai faktor pendugaan erosi yang diperoleh, erosi tahunan yang terjadi pada setiap lokasi pemantauan menurut umur revegetasi dan hutan alam dihitung dan dikelaskan. Nilai erosi dan tingat bahaya erosi disajikan pada Tabel 9. Pada tabel menunjukkan bahwa tingkat erosi untuk Site Lati Erosi tertinggi yang terjadi adalah sekitar 844,60 ton/ha per tahun, tergolong sangat tinggi dijumpai pada areal pemantauan umur revegetasi 0 tahun. Tingkat erosi kemudian menurun drastis menjadi hanya sekitar 47.1 ton/ha per tahun (tergolong rendah) pada areal revegetasi umur 1 tahun.

Tabel 9. Tingkat erosi dengan menggunakan metode USLE di Site Lati

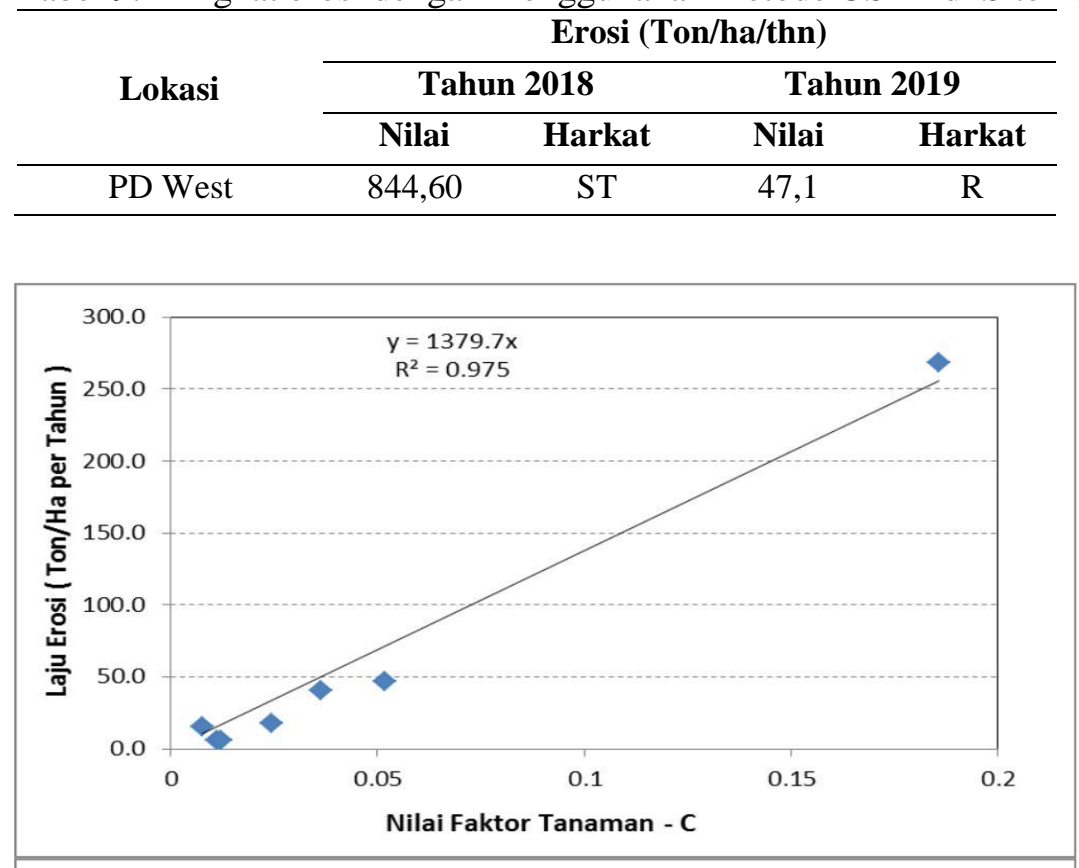

Gambar 3. Hubungan antara potensi erosi dengan nilai faktor tanaman pada Areal IPD West Site Lati

Pada lahan pemantauan menunjukan pada arael yang bervegetasi semakin efektif dalam mengendalikan erosi. Seperti terlihat pada Gambar 3, hal ini diperkuat oleh hasil analisis korelasi yang menunjukkan hubungan yang sangat kuat antara potensi erosi dan faktor tanaman dengan nilai koefisien determinasi sangat tinggi yaitu 0.975 untuk site Lati.

\section{C.3. Kesuburan Tanah}

Hasil analisa tanah menunjukan arel IPD West termasuk masuk dalam tanah marginal dengan pH 3 setelah dilakukan penanaman hydroseeding terdapat nilai kesuburan tanah yang meningkat 
dibandingkan dengan areal yang belum dilakukan penanaman covercrop, terlihat dari Gambar 4 berikut:

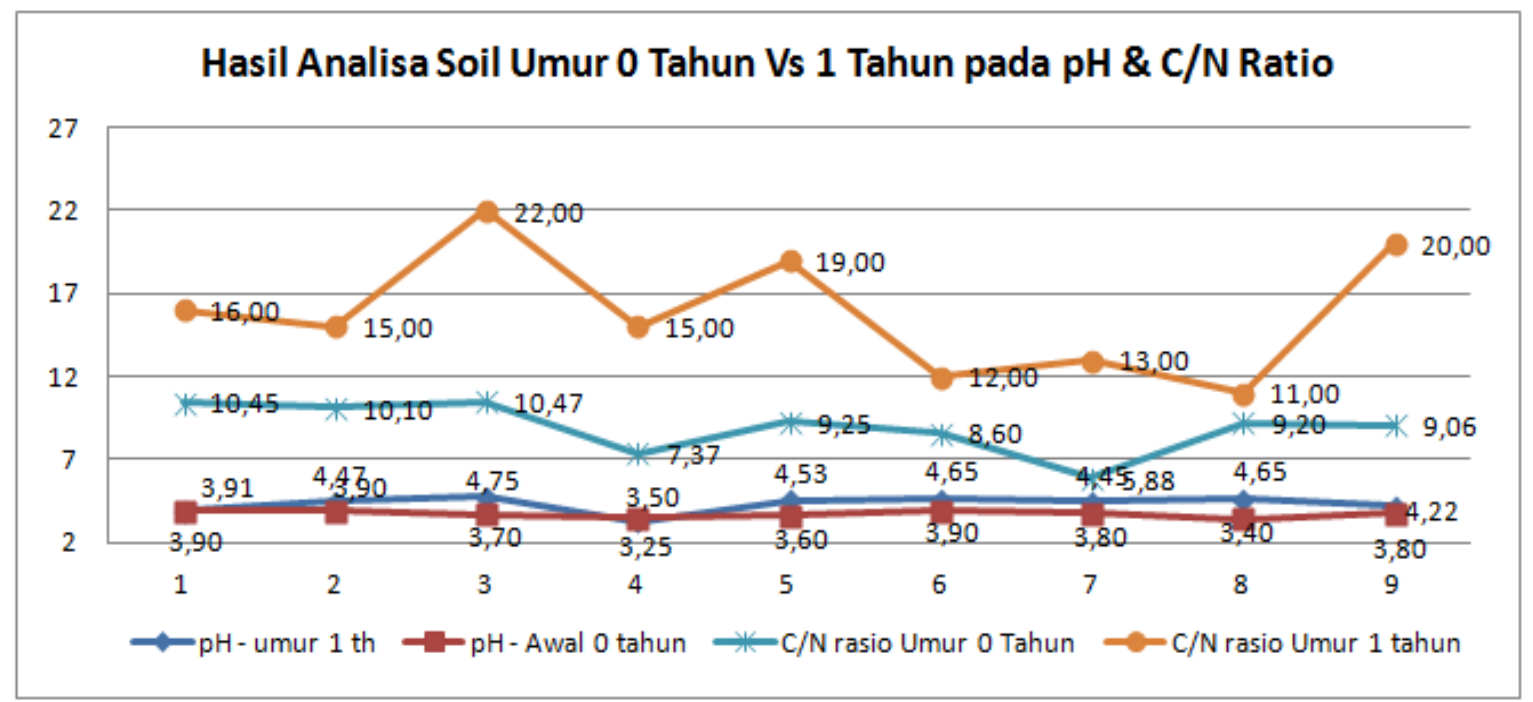

Gambar 4. Kondisi pH dan C/N rasio pada areal IPD West pada umur 0 tahun dan 1 tahun

Pada areal hydroseeding terjadi peningkatan $\mathrm{pH}$ dengan nilai penambahan 0,01 point dan maksimal dengan nilai penambahan 1,25 point. Nilai perbandingan karbon (bahan organik) dan nitrogen setelah umur 1 tahun 8 bulan juga mengalami kenaikan dengan penambahan nilai sebesar 1,8 point dan maksimal penambahan 11,53 point. Hal ini diduga karena perlakuan awal saat penyemprotan menggunakan material hydroseeding, yang mana campuran material didalamnya terdapat dosis kapur dolomit dengan dosis $500 \mathrm{~kg} / \mathrm{ha}$ dan bahan organik sebanyak 10 ton/Ha, memungkin juga penambahan bahan organik dari proses pelapukan beberapa bahan organik covercrop yang telah meranggas/mati.

\section{KESIMPULAN}

Dari hasil penelitian dan pembahasan kesimpulan sebagai berikut:

1. Persentase penutupan covercrop teknik hydroseeding pada lahan marginal mempunyai nilai keberhasilan yang cukup tinggi sebesar $90 \%$.

2. Tingkat laju erosi pada areal marginal yang belum dilakukan penanaman covercroping mempunyai tingkat laju erosi sangat tinggi sebesar 844,60 ton/ha/tahun sedangkan pada areal yang sudah dilakukan penanaman covercroping pada tingkat rendah dengan nilai 47,1 ton/ha/tahun.

3. Tingkat kesuburan tanah pada lahan marginal mengalami peningkatan setelah dilakukan penanaman covercrop dengan teknik hydroseeding.

\section{DAFTAR PUSTAKA}

Arsyad S. 2010. Konservasi Tanah dan Air. Edisi Kedua. PT Penerbit IPB Press. IPB Bogor.

Asdak, C., (2007). Hidrologi dan Pengelolaan Daerah Aliran Sungai. Gadjah Mada University Press, Yogyakarta.

Hammer, W.I., 1981. Soil Conservation Consultant Report. Soil Research Institute Indonesia. Technical Note No. 7.

Lal, R. 1977. Erosivity in tropical countries. IITA Paper Presented at the Expert Consultation on Methodology for Assessing Soil Degradation. Rome, 18-20 January 1977. Western Nigeria. I. Runoff, erosion and crop response, land Degaradtion and Development. 8:201-219. 
Moss, A.J. and T. W. Green. 1987. Erosive effects of large water drops (gravity drops) that fall from plant. Australia J. Soil Res. 25:9-20

Schwab GO, Frevert RK, Edminster TW, Barnes KK. 1981. Soil and water conservation engineering. Ed ke-3. John Wiley and Sons. New York.

Sinukaban, N. 2007. Konservasi Tanah dan Air. Kunci Pembangunan Berkelanjutan. DitJen RLPS, Jakarta

Wischmeier, W. H., Smith, D.D. 1978. Predicting rainfall erosion losses-a guide to conservation planning. U.S. Department of Agriculture, Agriculture Handbook No. 537. 